\title{
DOI https://doi.org/10.30525/978-9934-26-178-7-6
}

\section{ЛЮДИНА В ЕПОХУ НОВОЇ МЕДІЙНОСТІ: ПОНЯТІЙНО-ДІЯЛЬНІСНИЙ ДИСКУРС}

\author{
Півторак Д. В. \\ магістр культурологіі, \\ заступниия директора \\ Навчально-методичний цеентр культури і туризму Прикарпаття \\ м. Івано-Франківськ, Украӥна
}

У дуже загальних рисах різні дискурси нових медіа-досліджень часто збігаються з новими ЗМІ провістили справжню зміну відносно людської ідентичності або суб'єктивності. Це може бути в умови все більш грунтовної інтеграції повсякденного життя та медіасфери; змінюючи відносини між державними та приватними сферах або між індивідом (або місцевою громадою) та глобальним охопленням популярних засобів масової інформації і культурні форми; претензії на радикальні експерименти або грати з ідентичністю в деяких Інтернет-3МI; або зростаюча інтимність або гібридизація між людськими та технологічними ознаками в кіборг.

Отже, питання співвідношення між людиною і технологією в нових засобах масової інформації, навчання, як правило, розглядаються у відношенні питань ідентичності та суб'єктивності. Однак у дослідженнях медіа-технологій та ідентичності чи суб'єктивності точно не завжди зрозуміло, що мається на увазі під «ідентичністю». 3 одного боку - це може означати трохи більше, ніж повсякденний вибір про те, як людина вирішує представити себе світові (вибір наряду на день, перевага в моделі мобільного телефону та мелодію тощо), з іншого - сенс ідентичності «в стадії будівництва» передбачає більш фундаментальні зміни в сенсі самого себе, ближче до претензій до кіберкультурних досліджень.

Інтернет - найбільш широко доступне Інтернетсередовище, пропонуючи чіткі нові можливості для встановлених зв'язків між державним i приватним простором, громадськими та приватними особами. 3 початком роботи Інтернету в середині 1990-х років, персональна домашня сторінка незабаром стала досить доступною і явно новою формою виробництва засобів масової інформації. Проектування та публікація персонального веб-сайту було досить простим і недорогим, i дозволив дизайнерам звернутися до (потенційну) аудиторії у всьому 
світі або співпрацювати 3 географічно розподіленою спільнотою інтересів.

Сучасна людина, через свою включеність в медіа-простір, репрезентована в них такими статусами як: «цифровий абориген» (Digital Natives) (М. Пренскі), «цифровий мігрант», «аватар» тощо. Сам медіапростір можна охарактеризувати як:

- поєднання медіа-подієвості із реальністю, структурування практично усіх форм життєдіяльності людини (соціально-політична, соціокультурна, виробнича, освітня тощо);

- засіб соціального програмування та реалізації соціоінженерних проектів;

-незахищеність людини перед негативною інформацією, «патотекстом» (Б. Потятиник), що зумовлена апеляцією до підсвідомості, розігрування у свідомості сценаріїв утілення бажань, експлуатацією та деформацією психологічних ресурсів особистості [2, с. 124-169];

- маніпулювання свідомістю за допомогою поширення фейкових новин, або ж з умонтованою точкою зору тощо;

- відсутність чинника Іншого, значущість референтного статусу незнайомців у соціальних мережах;

- ерзац-свобода як вседозволеність, можливість «сховатися» за абстрактним ніком, штучною біографією тощо;

- ілюзія включеності в соціальний простір, комунікацію;

- симулякр («копії, що не мають оригіналу», Ж. Бодріяр, Ф. Вебстер) як основа медійної взаємодії, створення віртуалізованої Я-концепції, організації життєдіяльності в віртуальному світі (дружба, кохання, «будівництво міст і держав» тощо). І, як наслідок, дефіцит досвіду реального конкурентного життя;

-подолання межі між реальним та віртуальним (фальсифікація новин, реаліті-шоу тощо), що зумовлює суперечливе відчуття залученості до насиченого соціального буття, привчає жити серед віртуальних образів, віртуальних цінностей, забезпечує компенсацію реальних почуттів та переживань, створює умови для романтизації насильницьких стереотипів поведінки. I, як наслідок, - інтернетескапізм, фрейминг (приписування значень) як своєрідна соціокультурна реальність;

- можливості персонального маркетингу за допомогою соціальних ресурсів, технологій Viki зумовлює формування відчуття залученості до суспільних подій, власної самореалізації та самоздійснення.

Ідеологія тепер не вимагає сліпої віри суб'єкта, як це було в XX столітті. Швидше, вона поміщає його в позицію персонажа, який добре знає про обман і великодушно дозволяє себе обдурити. Давайте 26 
зізнаємося: кожен розуміє, що, наприклад, створення «власною унікальною ідентичності» за допомогою відтворення стилю і знакової системи, що мають відношення до комерційного масового виробництву, безглуздо. Але люди все одно продовжують купувати дорогі речі, вибираючи між стилем «мілітарі» або «богемним» цибулею, образами «хіпі», «мешканця гетто» або «тусовщика». Так що описані перемикання від ілюзії до її очікування в інтерактивних медіа можна розглядати як приклад якраз такої спільної явища. Як і класична ідеологія, класичний реалізм вимагає від суб'єкта повного прийняття ілюзії, принаймні на час іiї дії. А новий метареализм живе завдяки коливанню суб'єкта між ілюзією і ії руйнуванням, між зануренням у неї і зверненням до неї. Виявляється, суб'єкт має зараз куди більшу владу, ніж раніше, коли він міг деконструювати рекламу, газетні матеріали про скандали та інші інтерактивні медіа. Суб'єкт буквально інвестує, вкладається в ілюзію просто тому, що йому дана формальна, видима влада цю ілюзію контролювати.

Ігровий досвід вбудований в поточну практику нових засобів масової інформації, особливо тих, хто бере участь у відеоіграх, аудіовізуальному виробництві та спільному використанні в Інтернеті.

Оскільки програмне забезпечення проникає всюди - Google, Facebook, Amazon відстежують кожен наш крок, безперервно покращуючи себе і поставляються ними послуги - для сучасних аналітиків стає «просто необхідно мати можливість фіксувати і аналізувати досвід взаємодії, слідуючи за окремими користувачами в їх навігації по вебсайту або під час проходження відеоігри; вивчати інших гравців, а не спиратися в аналізі лише на свій особистий ігровий досвід», іншими словами, теоретик повинен представляти взаємодії в їх процесуальності у вигляді даних, які зможуть аналізувати програми. Для чого це потрібно, запитаєте ви? Щоб «зрозуміти, як люди конструюють смисли в результаті взаємодії з інтерфейсом і яким чином їх соціальний i культурний досвід опосередкований програмним забезпеченням» $[1$, c. $87-88]$.

Вплив Інтернету на людей постійно зростає. Інтернет - це посередник у моделях комунікації особистості, в споживанні, бронюванняі банківські операції, у віддалених групових заходах, включаючи пенсіонерів, розваги та ігри, обговорення та вирішення проблем,численні види співпраці та / або конфліктів.

Шеррі Теркл, директор Ініціативи Технології та особистості при Массачусетському технологічному інституті (MIT Initiative on Technology and Self), відома дослідниця проблеми взаємодії людини i технологій, звертає увагу на таку особливість молодих користувачів, як 
«тривога непідключеності», яка для деяких досягає рівня паніки. «Сучасні підлітки можуть всерйоз говорити про втрату iPhone -як про дуже значущу втрату. Бажання бути завжди в Мережі характерно для сучасної людини» [4].

Нові медіа надали нове середовище і засоби для соціалізації, тут люди не тільки експериментують зі своїм образом, але знаходять друзів, однодумців, вчаться спілкуватися і будувати відносини.

У XXI ст. змінилася сама природа ідентичності, причому не тільки для юних користувачів, але i для всіх, хто «живе» в мережевих спільнотах. Ідентичність людини, що живе в світі цифрових технологій, - це синтез образів, дослідів самовираження в реальному і віртуальному просторах. Найбільші зміни зазнає соціальна ідентичність, яка тепер, більше ніж будь-коли, формується не тільки на основі слів або дій самої особистості, але і того, що про неї говорять в інтернеті інші. Їх оцінки та коментарі загальнодоступні, важко контрольовані [3, с. 37].

\section{Література:}

1. Manovich L. The Language of New Media. The MIT Press, 2002 URL: https://quod.lib.umich.edu/cgi/t/text/text-idx?c=acls;cc=acls; $; i e w=t o c ;$ idno=heb31966.0001.001

2. Потятиник Б. В. Медіа: ключі до розуміння.Серія: Медіакритика / Борис Володимирович Потятиник. - Львів : ПАІС, 2004. - 312 с.

3. Palfrey John, Gasser Urs. Born Digital. Understanding the first generation of digital natives. N.Y., 2008. P. 37.

4. Sherry Turkle. Интервью для проекта Digital Nation. Life on the digital frontier URL: http://www.pbs.org/wgbh/pages/frontline/ digitalnation/interviews/turkle.html?utm_campaign=videoplayer\&utm_medi um=fullplayer\&utm_source=relatedlink $<$ 